Zeszyty Naukowe Szkoły Głównej Gospodarstwa Wiejskiego w Warszawie

Problemy Rolnictwa Światowego tom 18 (XXXIII), zeszyt 4, 2018: 382-394

DOI: 10.22630/PRS.2018.18.4.127

Krzysztof Piotr Pawłowski ${ }^{1}$

Uniwersytet Przyrodniczy w Poznaniu

\title{
Rola środków pochodzących z Unii Europejskiej w rozwoju pszczelarstwa na przykładzie Wojewódzkiego Związku Pszczelarzy w Poznaniu
}

\section{The role of funds from the European Union in the development of beekeeping on the example of the Provincial Union of Beekeepers in Poznań}

\begin{abstract}
Synopsis. Poza dostarczaniem niezwykle cennych produktów, pszczoły są jednym z gatunków zdolnych do zapylania roślin entomofilnych. Stąd wspieranie rozwoju pszczelarstwa w obliczu ich znaczenia dla ludzkości wydaje się być niezwykle istotne. W Polsce zadanie to jest realizowane także przy użyciu środków pochodzących z Unii Europejskiej w ramach Programów Wsparcia Rynku Produktów Pszczelich. Celem artykułu jest zatem określenie roli środków pochodzących z Unii Europejskiej w rozwoju pszczelarstwa w województwie wielkopolskim na przykładzie Wojewódzkiego Związku Pszczelarzy w Poznaniu. Do badań wykorzystano niepublikowane dane WZP w Poznaniu, a także wyniki przeprowadzonej ankiety. Wyniki badań wskazują na pozytywne oddziaływanie środków z UE na rozwój pszczelarstwa w województwie wielkopolskim, zwłaszcza ze względu na spore zainteresowanie mechanizmem wśród pszczelarzy.
\end{abstract}

Slowa kluczowe: pszczelarstwo, Wielkopolska, fundusze unijne, wsparcie pszczelarstwa

\begin{abstract}
In addition to providing extremely valuable products, bees are one of the species capable of pollinating entomophilic plants. Hence, supporting the development of beekeeping in the face of their importance to humanity seems to be extremely important. In Poland, this task is also carried out using funds from the European Union as part of the Bee Market Program Support Programs. The aim of the article is therefore to determine the role of funds originating from the European Union in the development of beekeeping in the Wielkopolskie voivodship on the example of the Provincial Union of Beekeepers in Poznań. First of all unpublished JPA data in Poznań, as well as the results of surveys were used for the research. The results of the research indicate a positive impact of EU funds on the development of beekeeping in the Wielkopolskie voivodship, especially due to the considerable interest in the mechanism among beekeepers.
\end{abstract}

Key words: beekeeping, Wielkopolska, EU funds, support for beekeeping

JEL Classification: O13, Q51, Q57

\section{Wprowadzenie}

Pszczoły są dla człowieka istotne od kilku tysięcy lat. Ogromne znaczenie pszczelarstwa dla ludzkości, a w szczególności dla sektora rolnego, wynika z dwóch

\footnotetext{
${ }^{1}$ mgr inż., Katedra Ekonomii i Polityki Gospodarczej w Agrobiznesie, Wydział Ekonomiczno-Społeczny, Uniwersytet Przyrodniczy w Poznaniu, ul. Wojska Polskiego 28, 60-637 Poznań, e-mail: krzysztof.pawlowski@up.poznan.pl, https://orcid.org/0000-0001-7194-4779
} 
aspektów. Po pierwsze, pszczoły dostarczają bardzo wielu wartościowych produktów, takich jak miód, propolis, pyłek pszczeli, pierzga i wiele innych. Z drugiej zaś strony są jednym z gatunków zdolnych do zapylania roślin entomofilnych, co stanowi główną przesłankę do ich użytkowania. Poprzez zapylanie możliwe jest zachowanie bioróżnorodności środowiska naturalnego, a także uzyskanie wyższych plonów wielu roślin użytkowych (Majewski 2012). Instytut Sadownictwa i Kwiaciarstwa szacuje, że wartość uzyskiwana dzięki zapylaniu roślin przez pszczoły jest ponad dwudziestokrotnie wyższa niż wartość wytwarzanych przez nie produktów (Madras-Majewska, Majewski, 2006). Przytoczone argumenty są głównymi przesłankami utrzymywania pszczół. Niestety pomimo relatywnie sporej liczby pni pszczelich, którą w Polsce szacuje się na ok. 1,55 mln (z czego 1,32 mln należy do pszczelarzy zrzeszonych w organizacjach pszczelarskich) (Semkiw, 2017), to według szacunków Instytutu Sadownictwa i Kwiaciarstwa (Oddział Pszczelarstwa), do zapylania sadów oraz rzepaków w Polsce potrzebnych jest około 2,5 mln rodzin pszczelich (Madras-Majewska, Majewski, 2006). Z kolei straty w gospodarce polskiej wynikające ze zbyt małej liczby pni pszczelich szacuje się na 2,5-3 mld złotych rocznie (Borowska, 2010).

Wyzwaniem dla pszczół i pszczelarzy staje się intensyfikacja rolnictwa. Wraz ze wzrostem jego intensywności rośnie także problem z zatruciami pszczół. Jak podaje Semkiw (2017), w 2017 roku w Polsce występowały liczne ostre zatrucia oraz podtrucia pszczół, głównie pochodzące z rzepaków, zbóż, malin, a także innych roślin uprawnych. Problemem w rozwoju pszczelarstwa i systematycznym zwiększaniu liczby rodzin pszczelich są również problemy z zimowaniem: przykładowo, zimy 2016/2017 nie przetrwała około $1 / 4$ rodzin pszczelich w Polsce.

$\mathrm{Z}$ jednej strony bardziej intensywne rolnictwo potrzebuje coraz więcej pszczół niezbędnych do zapylania coraz większego areału roślin entomofilnych, $\mathrm{z}$ drugiej zaś poprzez tę intensyfikację, a zwłaszcza bardziej powszechne używanie środków ochrony roślin szkodzących pszczołom, niekorzystanie wpływa na te zapylające owady. W warunkach Polski najważniejszymi roślinami entomofilnymi, których istnienie oraz plonowanie uzależnione jest od ich zapylenia, są krzewy owocowe, plantacje trwałe, rośliny sadownicze oraz rzepak (Majewski, 2017). Można zatem stwierdzić, że wraz z rozwojem rolnictwa niezbędny jest jednoczesny, dynamiczny rozwój pszczelarstwa. Jednak ze względu na charakterystykę pasiek w Polsce, rozwój ten wymaga pewnego impulsu, którym z pewnością mogą być środki finansowe wspierające pszczelarzy.

Pod względem ekonomicznym wyróżnia się następujące pasieki (Ostrowska, 1988): 1) amatorskie (prowadzone tylko dla przyjemności), 2) prowadzone w celu uzyskania dodatkowego dochodu (poza pracą zawodowa), 3) zawodowe (stanowiące główne źródło dochodu pszczelarza). Większość pasiek to pasieki hobbystyczne, które nie stanowią dla pszczelarza jedynego źródła utrzymania (Pawłowski, 2017). Ponadto większość pszczelarzy w Polsce to osoby w starszym wieku, co świadczy o malejącej popularności tego zajęcia. Za jedną z przyczyn takiego stanu rzeczy uznaje się niską rentowność prowadzonych gospodarstw pasiecznych (Karliński, 2015).

Różnice w strukturach pasiek w poszczególnych regionach są zdeterminowane przede wszystkim występowaniem pożytków pszczelich. W przypadku rzepaku w Polsce występuje bardzo duże zróżnicowanie regionalne w powierzchni uprawy tej entomofilnej rośliny. Województwo wielkopolskie jest jednym z liderów w produkcji, ustępując jedynie województwu dolnośląskiemu. W 2016 roku areał tej uprawy wynosił w Wielkopolsce 104 tys. ha, co daje niespełna $13 \%$ krajowej powierzchni (rys. 1). W pełni uzasadnia to 
znaczenie gospodarcze pszczelarstwa $\mathrm{w}$ tym województwie, a także podjęcie badań w zakresie oceny działań zmierzających do poprawy sytuacji pasiek, w tym także przy wykorzystaniu środków z Unii Europejskiej.

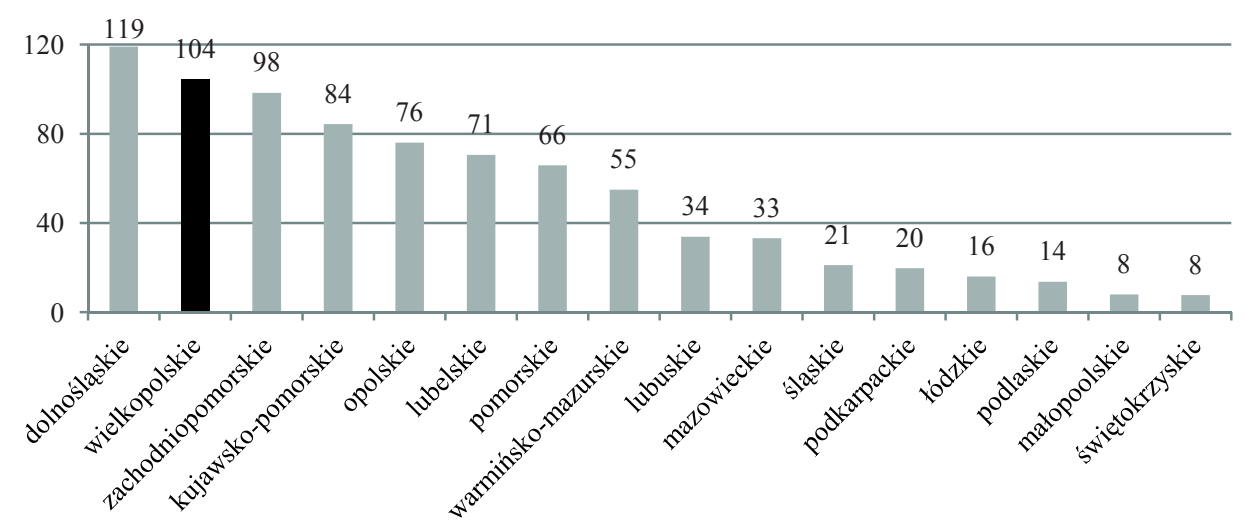

Rys. 1. Powierzchnia uprawy rzepaku w poszczególnych województwach w 2016 roku

Fig. 1. Area of rape cultivation in individual provinces in 2016

Źródło: opracowanie własne na podstawie danych GUS.

Unia Europejska stosuje wsparcie branży pszczelarskiej od 1997 roku, podkreślając wagę tego elementu we Wspólnej Polityce Rolnej. Jak podaje Agencja Rynku Rolnego (Sprawozdanie z..., 2016), przesłankami wpływającymi na dofinansowywanie działań państw członkowskich przez Komisję Europejską na rynku produktów pszczelich są: rozwój obszarów wiejskich, ujednolicenie warunków produkcji oraz zbytu produktów pochodzących od pszczół, zapobieganie rozdrobnienia produkcji i handlu miodem, utrzymanie równowagi ekologicznej, równoważnie popytu i podaży na miód, a także zwalczanie chorób pszczół (zwłaszcza warrozy). Obecnie udzielanie pomocy w sektorze pszczelarskim określa art. 55 rozporządzenia Parlamentu Europejskiego i Rady (UE) nr 1308/2013, zaś wcześniej obowiązującym aktem prawnym było rozporządzenie Rady (WE) nr 1234/2007. Komisja Europejska zatwierdza trzyletnie krajowe programy wsparcia pszczelarstwa, które następnie są realizowane przez działania państw członkowskich. W Polsce agencją realizującą mechanizm „Wsparcie rynku produktów pszczelich” była Agencja Rynku Rolnego (obecnie Krajowy Ośrodek Wsparcia Rolnictwa).

W przypadku Krajowych Programów Wsparcia Pszczelarstwa w latach 2010/2011, 2011/2012 oraz 2012/2013, Komisja Europejska ustaliła sześć kierunków wsparcia pszczelarstwa (Rozporządzenie Rady (WE) 1234/2007):

1. Pomoc techniczna skierowana do pszczelarzy i organizacji pszczelarzy;

2. Zwalczanie warrozy;

3. Racjonalizacja sezonowego przenoszenia uli;

4. Środki wspierające laboratoria przeprowadzające analizy produktów pszczelich w celu ułatwienia pszczelarzom wprowadzania do obrotu i podnoszenia wartości swoich produktów;

5. Środki mające na celu wsparcie zasiedlania uli w Unii; 
6. Współpraca $\mathrm{z}$ wyspecjalizowanymi podmiotami $\mathrm{w}$ zakresie wdrażania stosowanych programów naukowo-badawczych w dziedzinie pszczelarstwa i produktów pszczelich;

$\mathrm{Na}$ podstawie art. 55 rozporządzenia Parlamentu Europejskiego i Rady (UE) $\mathrm{nr}$ 1308/2013 dodano kolejne dwa kierunki:

7. Monitorowanie rynku;

8. Poprawa jakości produktów, aby skuteczniej pozycjonować produkty na rynku.

Państwa Wspólnoty mogą dowolnie dobierać instrumenty wsparcia z katalogu dostępnych działań, a także uszczegóławiać planowane do realizacji działania (Majewski, 2015). Polska korzysta z sześciu pierwotnie ustalonych kierunków. Środki finansowane przeznaczane na wsparcie pszczelarstwa przekazywane są w części przez państwa członkowskie, a w części przez Unię Europejską, która pokrywa do 50\% kosztów kwalifikowanych. Bardzo istotny jest podział środków pomiędzy kraje członkowskie, który dokonywany jest przy pomocy określenia udziału liczby pni pszczelich w danym kraju, do ogólnej liczby pni pszczelich we Wspólnocie (Bolisęga, 2004).

W latach 2005-2016 Agencja Rynku Rolnego wypłaciła w ramach Krajowych Programów Wsparcia Pszczelarstwa ponad $206 \mathrm{mln}$ zł. Zauważalny jest stopniowy wzrost wypłacanego wsparcia w poszczególnych latach (rys. 2), który przyjmuje charakter trendu liniowego, dlatego w następnych latach można się spodziewać kolejnych wzrostów wypłaconych środków. Sytuacja taka może mieć miejsce z jednej strony ze względu na rosnącą liczbę pni pszczelich, z drugiej zaś na coraz lepsze i pełniejsze wykorzystanie przyznawanych przez UE środków.

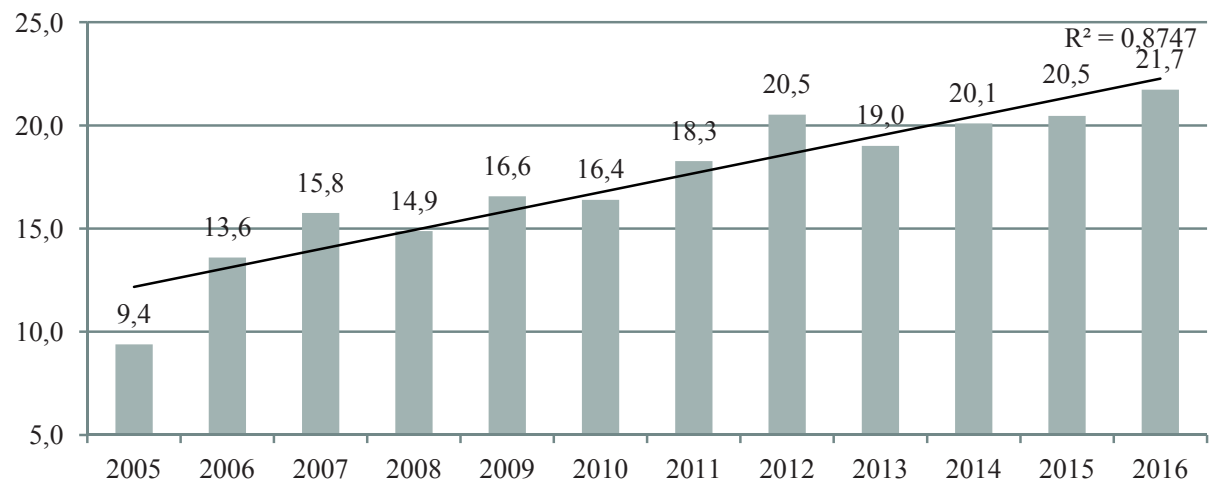

Rys. 2. Wypłaty netto w ramach programów "Wsparcia rynku produktów pszczelich" (mln zł)

Fig. 2. Net payments under the "Supports for bee products market" programs (PLN m)

Źródło: opracowanie własne na podstawie danych ze sprawozdań ARR (2005-2016).

Celem artykułu jest określenie roli środków pochodzących z Unii Europejskiej w rozwoju pszczelarstwa $\mathrm{w}$ województwie wielkopolskim na przykładzie Wojewódzkiego Zwiazku Pszczelarzy w Poznaniu. Województwo wielkopolskie należy do województw, w których pszczelarstwo ma największe znaczenie gospodarcze. Wiąże się to głównie ze sporą powierzchnią upraw roślin entomofilnych takich jak rzepak. Dlatego istotne jest określenie stanu pasiek w tym województwie, a także perspektyw ich rozwoju, zwłaszcza w aspekcie możliwości wsparcia pszczelarstwa środkami pochodzącymi z Unii Europejskiej. 


\section{Dane i metody}

W województwie wielkopolskim istnieje łącznie pięć organizacji zrzeszających pszczelarzy. W związku z tym niezwykle trudne byłoby pozyskanie porównywalnych danych dla każdej z tych niezależnych od siebie organizacji. Dlatego zdecydowano się pozyskać dane z Wojewódzkiego Związku Pszczelarzy w Poznaniu (WZP), który ma największe znaczenie i zrzesza największą liczbę pszczelarzy. Jego udział w pszczelarstwie wielkopolskim ogółem prezentuje tabela 1. Przyjęto założenie, że organizacja ta będzie stanowiła punkt odniesienia do określenia sytuacji pszczelarstwa w Wielkopolsce w kontekście otrzymywanych środków z UE w ramach Programów Wsparcia Rynku Produktów Pszczelich.

Głównym materiałem źródłowym poddanym analizie są niepublikowane dane Wojewódzkiego Związku Pszczelarzy w Poznaniu dotyczące ilościowych i finansowych efektów wdrażania Programów Wsparcia Rynku Produktów Pszczelich. Dane te dotyczą ostatniego sezonu Programu na lata 2010-2013 a także wszystkich trzech sezonów Programu 2013-2016. W opisie badań przyjęto uproszczone nazewnictwo kierunków wsparcia stosowane przez WZP. Dane pochodzą z projektów Programów tworzonych przez zarząd WZP, a także z umów dotyczących przyznania wsparcia w ramach poszczególnych kierunków. Na tej podstawie określono liczbę beneficjentów oraz kwoty przeznaczane na poszczególne działania.

W celu określenia znaczenia pszczelarstwa dla gospodarski (w tym głównie dla rolnictwa), skorzystano z danych Głównego Urzędu Statystycznego oraz Instytutu Ogrodnictwa (Oddział Pszczelnictwa). Ponadto użyto danych ze sprawozdań Agencji Rynku Rolnego (dotyczących wielkości środków wypłacanych w ramach Programów Wsparcia Rynku Produktów Pszczelich). Bardzo istotnym materiałem pierwotnym były wyniki badania ankietowego przeprowadzonego podczas Wielkopolskiego Forum Pszczelarskiego w Sielinku. Respondentami byli członkowie Wojewódzkiego Związku Pszczelarzy w Poznaniu w liczbie 133 osób. Pytania zawarte w ankiecie dotyczyły uczestnictwa pszczelarzy w Programie w przeszłości, chęci uczestnictwa w przyszłości, a także preferencji odnośnie zmiany wielkości pasiek. Dane zostały poddane analizie ilościowej oraz jakościowej. Dzięki temu możliwe stało się określenie podejścia wielkopolskich pszczelarzy do otrzymywanych z UE środków, a także ustalenie wpływu, jakie mają na rozwój pasiek.

Aby zrealizować główny cel artykułu, w opracowaniu oraz ocenie materiału badawczego posłużono się następującymi metodami: porównawczą, opisową, graficzną, tabelaryczną, a także analizy przyczynowo-skutkowej.

\section{Wyniki badań}

Jak podają dane Instytutu Ogrodnictwa w Puławach, liczba pszczelarzy w województwie wielkopolskim zwiększała się systematycznie w latach 2012-2017, osiagając w ostatnim roku analizy 5680 pszczelarzy. Podobna tendencja miała miejsce w WZP, gdzie w 2017 roku zrzeszonych było 1411 osób, co stanowiło niespełna 25\% wielkopolskich pszczelarzy ogółem. Wzrastała także liczba pni pszczelich. W 2017 roku niespełna 41 tysięcy pni należących do członków WZP, stanowiło ponad 32\% pni w Wielkopolsce ogółem. Wyższy udział w strukturze pni pszczelich niż w strukturze pszczelarzy świadczy o większej koncentracji pni pszczelich w 
pasiekach zrzeszonych w WZP. Pszczelarze WZP posiadają większe pasieki od pozostałych pszczelarzy w Wielkopolsce średnio o 5 uli.

Tabela 1. Wojewódzki Związek Pszczelarzy w Poznaniu na tle pszczelarstwa w Wielkopolsce

Table 1. Participation of the Provincial Union of Beekeepers in Poznań in the beekeeping of Greater Poland

\begin{tabular}{|c|c|c|c|c|c|c|c|c|}
\hline \multirow{2}{*}{ Rok } & \multicolumn{3}{|c|}{ Województwo wielkopolskie ogółem* } & \multicolumn{3}{|c|}{$\begin{array}{c}\text { Wojewódzki Związek Pszczelarzy } \\
\text { w Poznaniu }\end{array}$} & \multicolumn{2}{|c|}{$\begin{array}{c}\text { Udział WZP } \\
\text { w województwie } \\
\text { wielkopolskim }\end{array}$} \\
\hline & $\begin{array}{c}\text { Liczba } \\
\text { pszczelarzy }\end{array}$ & $\begin{array}{l}\text { Liczba pni } \\
\text { pszczelich }\end{array}$ & $\begin{array}{l}\text { Średnia } \\
\text { wielkość } \\
\text { pasieki }\end{array}$ & $\begin{array}{c}\text { Liczba } \\
\text { pszczelarzy }\end{array}$ & $\begin{array}{l}\text { Liczba pni } \\
\text { pszczelich }\end{array}$ & $\begin{array}{l}\text { Średnia } \\
\text { wielkość } \\
\text { pasieki }\end{array}$ & $\begin{array}{c}\% \\
\text { pszczelarzy }\end{array}$ & $\begin{array}{c}\% \text { pni } \\
\text { pszczelich }\end{array}$ \\
\hline 2012 & 4213 & 102002 & 24,2 & 1078 & 31854 & 29,5 & 25,6 & 31,2 \\
\hline 2013 & 4606 & 111079 & 24,1 & 1148 & 33472 & 29,2 & 24,9 & 30,1 \\
\hline 2014 & 4913 & 116152 & 23,6 & 1310 & 35995 & 27,5 & 26,7 & 31,0 \\
\hline 2015 & 5181 & 115044 & 22,2 & 1341 & 37372 & 27,9 & 25,9 & 32,5 \\
\hline 2016 & 5377 & 121791 & 22,7 & 1387 & 39733 & 28,6 & 25,8 & 32,6 \\
\hline 2017 & 5680 & 126438 & 22,3 & 1411 & 40618 & 28,8 & 24,8 & 32,1 \\
\hline
\end{tabular}

*Liczba pszczelarzy oraz pni pszczelich określona na podstawie danych z Powiatowych Inspektoratów Weterynarii

Źródło: opracowanie własne na podstawie danych WZP w Poznaniu oraz „Sektor pszczelarski w Polsce...” (2017).

Wielkopolskie pasieki rokrocznie otrzymuja ponad dwa miliony złotych w ramach Programów wsparcia pszczelarstwa (tab. 2). Znaczącą czesść tej sumy wypłacana jest pszczelarzom WZP, którzy otrzymują nieco ponad $1 / 3$ kwoty przeznaczonej dla województwa wielkopolskiego. To zdecydowanie wyższy udział w strukturze wypłat, niż udział pszczelarzy w ich ogólnej liczbie. Ponadto wskaźnik udziału WZP w wypłatach dla Wielkopolski jest średnio o 2 punkty procentowe wyższy niż wskaźnik udziału pni pszczelich. Świadczy to o lepszym wykorzystaniu możliwych do pozyskania środków.

Tabela 2. Wypłaty środków finansowych z Programów „Wsparcia Rynku Produktów Pszczelich” w poszczególnych sezonach

Table 2. Payments of funds from the "Support of the bee products market" programs in seasons

\begin{tabular}{l|ccc}
\hline \multicolumn{1}{c|}{ Sezon } & $\begin{array}{c}\text { Województwo } \\
\text { wielkopolskie ogółem } \\
\text { (tys. zł) }\end{array}$ & $\begin{array}{c}\text { Wojewódzki Związek } \\
\text { Pszczelarzy w Poznaniu } \\
\text { (tys. zł) }\end{array}$ & $\begin{array}{c}\text { Udział WZP w wypłatach środków } \\
\text { finansowych w województwie } \\
\text { wielkopolskim }(\%)\end{array}$ \\
\hline $2012 / 2013$ & 2215 & 738 & 33,3 \\
$2013 / 2014$ & 2021 & 688 & 34,0 \\
$2014 / 2015$ & 2068 & 718 & 34,7 \\
$2015 / 2016$ & 2191 & 740 & 33,8 \\
Lącznie: & 8495 & 2884 & 34,0 \\
\hline
\end{tabular}

Źródło: Opracowanie własne na podstawie danych WZP w Poznaniu oraz Sprawozdań z działalność ARR (20132016)

Powyższe wnioski potwierdzają także dane zawarte w tabeli 3, dotyczące wysokości wypłat środków finansowych $\mathrm{w}$ ramach programów wsparcia pszczelarstwa w przeliczeniu na jednego pszczelarza oraz jeden pień pszczeli. Członkowie WZP w każdym 
z analizowanych sezonów otrzymywali średnio większe wsparcie. Co prawda w przypadku części kierunków wysokość możliwych do uzyskania środków finansowych jest uzależniona od wielkości pasieki (np. w przypadku zakupu sprzętu pszczelarskiego limit stanowi iloczyn posiadanych pni pszczelich oraz kwoty 50 zł), co sprawia, że w sytuacji wyższej średniej wielkości pasiek niejako automatycznie zwiększa się finansowanie na jedną pasiekę. Dzięki temu pasieki zrzeszone w WZP otrzymywały w latach 2012-2016 średnio o 170 zł więcej rocznie w przeliczeniu na jedną pasiekę. Jeżeli chodzi natomiast o wsparcie na jeden pień pszczeli, to ule w WZP były również lepiej dofinansowywane, jednak tutaj różnica nie jest tak wyraźna: średnio o 0,60 zł więcej niż w przypadku pozostałych pasiek w Wielkopolsce.

Jak wykazano, Wojewódzki Związek Pszczelarzy w Poznaniu jest znaczącym beneficjentem środków pochodzących z programów wsparcia pszczelarstwa. W dalszej części artykułu skoncentrowano się na efektach ilościowych oraz finansowych wdrażanych przez niego działań.

Tabela 3. Wypłaty środków finansowych z Programów „Wsparcia Rynku Produktów Pszczelich” w poszczególnych sezonach w przeliczeniu na jednego pszczelarza oraz jeden pień pszczeli w województwie wielkopolskim oraz w Wojewódzkim Związku Pszczelarzy w Poznaniu (zł)

Table 3. Payments of funds from the "Support Programs for the Bee Products Market" programs in individual seasons per one beekeeper and one beech stump in the Greater Poland Voivodeship and in the Provincial Beekeepers Association in Poznań (PLN)

\begin{tabular}{l|cccc}
\hline \multirow{2}{*}{ Sezon } & \multicolumn{2}{|c}{ Wsparcie na pszczelarza } & \multicolumn{2}{c}{ Wsparcie na pien pszczeli } \\
& WLKP & WZP & WLKP & WZP \\
\hline $2012 / 2013$ & 481 & 685 & 21,7 & 22,1 \\
$2013 / 2014$ & 411 & 599 & 18,2 & 19,1 \\
$2014 / 2015$ & 399 & 548 & 17,8 & 19,2 \\
$2015 / 2016$ & 407 & 552 & 19,0 & 18,6 \\
Średnio: & 425 & 596 & 19,2 & 19,8 \\
\hline
\end{tabular}

Źródło: opracowanie własne na podstawie danych WZP w Poznaniu, Sprawozdań z działalność ARR (2013-2016) oraz „Sektor pszczelarski w Polsce...” (2012-2017).

Zdecydowanie dominującymi kierunkami wsparcia w strukturze wypłat środków był zakup sprzętu pszczelarskiego oraz zakup leków (tab. 4).

Tabela 4. Wypłaty środków finansowych w ramach poszczególnych kierunków wsparcia (tys. zł)

Table 4. Payments of funds under individual support directions (PLN thousand)

\begin{tabular}{l|cccccccccccc}
\hline \multirow{2}{*}{ Sezon } & \multicolumn{2}{|c}{ Zakup pszczół } & \multicolumn{2}{c}{ Zakup sprzętu } & \multicolumn{2}{c}{ Zakup leków } & \multicolumn{2}{c}{ Zakup lawet } & \multicolumn{3}{c}{ Szkolenia } & \multicolumn{2}{c}{ Analizy } \\
& P* & U* & P & U & P & U & P & U & P & U & P & U \\
\hline $2012 / 2013$ & 283,2 & 168,0 & 329,4 & 262,7 & 442,0 & 272,1 & 35,0 & 24,5 & 22,8 & 15,8 & - & - \\
$2013 / 2014$ & 241,3 & 169,0 & 371,6 & 312,2 & 340,1 & 287,9 & 4,6 & 4,7 & 13,8 & 13,8 & 4,0 & 1,6 \\
$2014 / 2015$ & 234,9 & 156,0 & 305,6 & 305,6 & 287,3 & 253,8 & 11,4 & 11,4 & 13,1 & 13,1 & - & - \\
$2015 / 2016$ & 236,2 & 145,3 & 317,2 & 317,2 & 314,9 & 251,1 & 21,1 & 19,1 & 13,5 & 13,5 & 2,2 & 2,2 \\
Lącznie: & 995,6 & 638,3 & 1323,9 & 1197,7 & 1384,3 & 1064,8 & 72,1 & 59,6 & 63,2 & 56,2 & 6,2 & 3,8 \\
\hline
\end{tabular}

Źródło: opracowanie własne na podstawie danych WZP w Poznaniu (* P - kwota w projekcie, U - kwota w umowie). 
Łącznie w trakcie trwania czterech edycji Programu na każde $\mathrm{z}$ tych działań wydatkowano ponad milion złotych. Zaledwie 3,8 tys. zł przeznaczono na analizy jakości miodu. Stosunkowo niewielkie środki przekazano także na zakup lawet (łącznie 59,6 tys. zł) oraz na szkolenia (56,2 tys. zł). Zauważalne są także pewne tendencje dotyczące wielkości wypłaconego wsparcia w poszczególnych kierunkach. $\mathrm{Na}$ przestrzeni analizowanych sezonów wzrastało finansowanie zakupu sprzętu pszczelarskiego, z kolei coraz mniej środków wypłacano na zakup pszczół oraz leków.

Efekty ilościowe określają liczbę zakupionych jednostek danego rodzaju produktu w ramach każdego kierunku wsparcia (tab. 5). W ujęciu tym, zarówno zaplanowano jak i zakupiono najwięcej leków (w ich skład wchodzą głównie leki wspomagające zwalczanie warrozy). Łącznie w ciągu czterech sezonów w ramach programu zakupiono niespełna 35 tys. jednostek lekowych (z ponad 50 tys. planowanych do zakupu). Spore zainteresowanie budził także zakup pszczół (zarówno matek pszczelich jak i odkładów ${ }^{2}$, których liczbę w niniejszej analizie zsumowano): łącznie zakupiono niespełna 13 tys. matek pszczelich oraz odkładów. Zrealizowano także sporo inwestycji związanych z zakupem sprzętu pszczelarskiego, łącznie ponad 4 tys. sztuk. Nadmienić jednak należy, że do skorzystania z dofinansowania do zakupu sprzętu uprawnieni byli tylko pszczelarze, których pasieki liczyły co najmniej 20 pni pszczelich. Drugim z ograniczeń jest maksymalna wielkość ekonomiczna gospodarstwa lub pasieki, ustalona na poziomie $4 \mathrm{ESU}^{3}$. Te wymagania wykluczają najmniejszych pszczelarzy z jednej strony, oraz osoby prowadzące dodatkowo gospodarstwa rolne $\mathrm{z}$ drugiej. $\mathrm{Z}$ kolei do zakupu pszczół oraz leków w ramach programu upoważnieni są wszyscy członkowie Związku.

Tabela 5. Efekty ilościowe Programów „Wsparcia Rynku Produktów Pszczelich” w analizowanych latach: liczba planowanych do finansowania oraz zakupionych jednostek danego produktu

Table 5. Quantitative effects of the "Support of the bee products market" programs in the analyzed years: the number of planned for financing and purchased units of a given product

\begin{tabular}{c|cccccccccccc}
\hline \multirow{2}{*}{ Sezon } & \multicolumn{2}{|c}{ Zakup pszczół } & \multicolumn{2}{c}{ Zakup sprzętu } & \multicolumn{2}{c}{ Zakup leków } & \multicolumn{2}{c}{ Zakup lawet } & \multicolumn{2}{c}{ Szkolenia } & \multicolumn{3}{c}{ Analizy } \\
& P* & Z* & P & Z & P & Z & P & Z & P & Z & P & Z \\
\hline $2012 / 2013$ & 6000 & 3264 & 333 & 351 & 13900 & 6936 & 10 & 7 & 4 & 4 & 0 & 0 \\
$2013 / 2014$ & 4200 & 3004 & 1731 & 1300 & 17700 & 7759 & 3 & 3 & 7 & 7 & 40 & 16 \\
$2014 / 2015$ & 4050 & 3229 & 1456 & 1228 & 10440 & 9050 & 4 & 4 & 6 & 6 & 0 & 0 \\
$2015 / 2016$ & 4110 & 3447 & 1491 & 1186 & 11700 & 10594 & 4 & 4 & 6 & 6 & 20 & 20 \\
Łącznie: & 18360 & 12944 & 5011 & 4065 & 53740 & 34339 & 21 & 18 & 23 & 23 & 60 & 36 \\
\hline
\end{tabular}

Źródło: opracowanie własne na podstawie danych WZP w Poznaniu (* P-planowana ilość, Z - zakupiona ilość).

Bardzo nagłośnionym $\mathrm{w}$ mediach kierunkiem wsparcia jest zakup lawet umożliwiających mobilność pasiek i przemieszczanie się w rejony, gdzie występują najlepsze pożytki. Jak jednak można zauważyć, w praktyce niewielu pszczelarzy

\footnotetext{
${ }^{2}$ Różnica pomiędzy matką pszczelą a odkładem polega na tym, że odkładem pszczelim nazywamy plastry z pokarmem i czerwiem wraz z obsiadającymi je pszczołami, które zostały pobrane z jednej lub kilku rodzin i umieszczone w nowym ulu, stanowiąc w pełni samodzielną rodzinę pszczelą. Matka pszczela jest natomiast samodzielnie umieszczana w ulu, w którym już znajdują się pszczoły. Najczęściej wprowadza się ją w celu poprawy właściwości genetycznych posiadanych pszczół.

3 Jednostka ESU (European Size Unit) wyraża wielkość ekonomiczną gospodarstw i określana jest na podstawie standardowej nadwyżki bezpośredniej produkcji; 1 ESU=1200 EUR.
} 
zdecydowało się na skorzystanie $\mathrm{z}$ tej formy wsparcia. W trakcie czterech sezonów zakupiono zaledwie 18 lawet.

W ramach Programu możliwe było także korzystanie ze szkoleń, które organizował WZP (liczby w tabeli dotyczą godzin ich trwania). Najmniej popularnym działaniem okazały się analizy jakości miodu, z których skorzystano tylko w dwóch sezonach, łącznie pobierając do badań 36 próbek.

Poza liczbą zakupionych w ramach wsparcia jednostek, istotna jest także liczba beneficjentów, którzy skorzystali ze wsparcia w ramach poszczególnych kierunków (tab. 5). W tym aspekcie również dominował zakup leków, z którego corocznie korzystało ponad tysiąc pszczelarzy (w trakcie 4 lat 4646 osób). Zakupu pszczół dokonywało pomiędzy 515 a 609 beneficjentów (łącznie 2303osoby). Ponad 200 pasiek rocznie dokonywało inwestycji w sprzęt korzystając ze wsparcia, a łącznie w badanych latach 18 zakupiło lawety do transportu pszczół. W szkoleniach wzięło udział 1450 pszczelarzy, a próbki do badań jakości miodu w ciągu czterech lat pobrano z zaledwie 6 pasiek.

Tabela 6. Efekty ilościowe Programów „Wsparcia Rynku Produktów Pszczelich” w analizowanych latach: liczba planowanych beneficjentów oraz beneficjentów, którym wypłacono środki finansowe w ramach poszczególnych kierunków wsparcia

Table 6. Quantitative effects of the "Support of the bee products market" programs in the analyzed years: the number of beneficiaries and beneficiaries planned, for which financial resources were disbursed under the particular directions of support

\begin{tabular}{c|cccccccccccc}
\hline \multirow{2}{*}{ Sezon } & \multicolumn{2}{c}{ Zakup pszczół } & \multicolumn{2}{c}{ Zakup sprzętu } & \multicolumn{2}{c}{ Zakup leków } & \multicolumn{2}{c}{ Zakup lawet } & \multicolumn{2}{c}{ Szkolenia } & \multicolumn{2}{c}{ Analizy } \\
& P* & Z* & P & Z & P & Z & P & Z & P & Z & P & Z \\
\hline $2012 / 2013$ & 850 & 609 & 333 & 213 & 1300 & 1091 & 10 & 7 & 400 & 400 & 0 & 0 \\
$2013 / 2014$ & 650 & 515 & 1731 & 238 & 1290 & 1181 & 3 & 3 & 350 & 350 & 12 & 2 \\
$2014 / 2015$ & 610 & 603 & 1456 & 236 & 1250 & 1171 & 4 & 4 & 350 & 350 & 0 & 0 \\
$2015 / 2016$ & 645 & 576 & 1491 & 246 & 1290 & 1203 & 4 & 4 & 350 & 350 & 2 & 4 \\
Lącznie: & 2755 & 2303 & 5011 & 933 & 5130 & 4646 & 21 & 18 & 1450 & 1450 & 14 & 6 \\
\hline
\end{tabular}

Źródło: Opracowanie własne na podstawie danych WZP w Poznaniu (* P- planowana liczba beneficjentów,

Z - liczba beneficjentów, którym wypłacono środki finansowe)

Jedynym działaniem zrealizowanym w stu procentach w stosunku do zaplanowanej liczby zarówno jednostek jak i beneficjentów były szkolenia (tab. 7). Można to thumaczyć faktem posiadania największej kontroli nad tym działaniem przez zarząd WZP, gdyż to właśnie zarząd organizuje i przeprowadza szkolenia, dzięki czemu może w pełni wykorzystać zaplanowane na ten cel środki. Pod względem liczby zakupionych jednostek w odniesieniu do liczby planowanych do zakupu, satysfakcjonująco zostały zrealizowane działania związane z zakupem lawet (86\%) oraz zakupem sprzętu (81\%). Najmniej jednostek zaplanowanych do zakupu zrealizowano $\mathrm{w}$ ramach działania analiz miodu $(60 \%)$ oraz zakupu leków (64\%). Pszczelarze najchętniej korzystali z zakupu leków, lawet, pszczół oraz sprzętu. We wszystkich tych działaniach poziom wykorzystania programu pod względem liczby beneficjentów wynosił niespełna $80 \%$ lub więcej. Warto odnotować, że w sezonie 2012/2013 zakupiono o 5\% jednostek sprzętu więcej niż pierwotnie planowano. Świadczyć to może o lepszym planowaniu działań przez WZP w kolejnych latach z jednej strony, a także większym zainteresowaniem wśród pszczelarzy z drugiej. 
Tabela 7. Wykorzystanie programu w ujęciu ilościowym w odniesieniu do jednostek danego produktu oraz beneficjentów $(\%)$

Table 7. Use of the program in terms of quantity in relation to units of a given product and beneficiaries (\%

\begin{tabular}{c|cccccccccccc}
\hline \multirow{2}{*}{ Sezon } & \multicolumn{2}{c}{ Zakup pszczół } & \multicolumn{2}{c}{ Zakup sprzętu } & \multicolumn{2}{c}{ Zakup leków } & \multicolumn{2}{c}{ Zakup lawet } & \multicolumn{2}{c}{ Szkolenia } & \multicolumn{2}{c}{ Analizy } \\
& J* & B* & J & B & J & B & J & B & J & B & J & B \\
\hline $2012 / 2013$ & 54 & 72 & 105 & 76 & 50 & 84 & 70 & 70 & 100 & 100 & - & - \\
$2013 / 2014$ & 72 & 79 & 75 & 79 & 44 & 92 & 100 & 100 & 100 & 100 & 40 & 17 \\
$2014 / 2015$ & 80 & 99 & 84 & 76 & 87 & 94 & 100 & 100 & 100 & 100 & - & - \\
$2015 / 2016$ & 84 & 89 & 80 & 82 & 91 & 93 & 100 & 100 & 100 & 100 & 100 & 200 \\
Lącznie: & 71 & 84 & 81 & 78 & 64 & 91 & 86 & 86 & 100 & 100 & 60 & 42 \\
\hline
\end{tabular}

Źródło: opracowanie własne na podstawie danych WZP w Poznaniu (* J- jednostki inwestycyjne, B beneficjenci).

Każdy z kierunków wsparcia posiada określony poziom zwrotu kosztów kwalifikowanych inwestycji (tab. 8). W przypadku szkoleń oraz analiz jakości miodu z Programu finansowana jest całość kosztów ich realizacji ${ }^{4}$. Pszczelarze otrzymują $80 \%$ zwrotu kosztów zakupu leków, 70\% kosztów zakupu pszczół oraz 60\% zakupu sprzętu i lawet. Refundacja tak jak w przypadku innych form wsparcia z UE nie obejmuje podatku od towarów i usług.

Najpełniej wykorzystanymi kierunkami wsparcia na przestrzeni analizowanego okresu były zakup sprzętu pszczelarskiego oraz szkolenia. W ich ramach wydatkowano niespełna $90 \%$ planowanych do zrealizowania środków. W pozostałych działaniach zakładany pierwotnie plan finansowy zrealizowano w granicach od 61,2 do 71,7\%. Niepełne wykorzystanie środków finansowych przez pszczelarzy może świadczyć o pewnej nieefektywności i niechęci do korzystania z działań Programu. Z drugiej jednak strony może to być oznaka sprawności działania zarządu WZP, który dzięki zaplanowaniu wyższych kwot wsparcia w poszczególnych kierunkach umożliwia skorzystanie ze wsparcia wszystkim chętnym pszczelarzom, którzy spełniają warunki dotyczące poszczególnych działań. Świadczy to także o dalszym potencjale rozwoju wielkopolskich pasiek, które w kolejnych okresach programowania mogą w jeszcze większym stopniu korzystać z oferowanego wsparcia.

Tabela 8. Poziom wsparcia oraz wykorzystania poszczególnych kierunków wsparcia (\%)

Table 8. The level of support and the use of particular directions of support (\%)

\begin{tabular}{|c|c|c|c|c|c|c|c|c|c|c|c|c|}
\hline \multirow{2}{*}{ Sezon } & \multicolumn{2}{|c|}{ Zakup pszczół } & \multicolumn{2}{|c|}{ Zakup sprzętu } & \multicolumn{2}{|c|}{ Zakup leków } & \multicolumn{2}{|c|}{ Zakup lawet } & \multicolumn{2}{|c|}{ Szkolenia } & \multicolumn{2}{|c|}{ Analizy } \\
\hline & $\mathrm{PW}^{*}$ & $\mathrm{~W}^{*}$ & PW & W & PW & W & PW & W & PW & W & PW & W \\
\hline $2012 / 2013$ & \multirow{4}{*}{70} & 58,5 & \multirow{4}{*}{60} & 79,0 & 100 & 61,6 & \multirow{4}{*}{60} & 70,0 & \multirow{4}{*}{100} & 69,1 & & - \\
\hline $2013 / 2014$ & & 60,7 & & 78,5 & & 67,9 & & 78,2 & & 96,8 & \multirow{3}{*}{100} & 40,0 \\
\hline $2014 / 2015$ & & 65,2 & & 99,4 & 80 & 82,7 & & 88,1 & & 99,9 & & - \\
\hline $2015 / 2016$ & & 60,8 & & 99,7 & & 79,7 & & 64,3 & & 100,0 & & 100,0 \\
\hline Łącznie: & - & 61,2 & - & 88,5 & - & 71,6 & - & 71,7 & - & 88,1 & - & 61,6 \\
\hline
\end{tabular}

Źródło: opracowanie własne na podstawie danych WZP w Poznaniu (* PW- procentowy poziom wsparcia, Wwykorzystanie środków).

\footnotetext{
${ }^{4}$ W sezonie 2012/2013 w stu procentach był także finansowany zakup leków.
} 
Reasumując, łącznie w trakcie czterech sezonów Programu Wsparcia Rynku Produktów Pszczelich realizowanego przez Wojewódzki Związek Pszczelarzy w Poznaniu, największy udział $\mathrm{w}$ strukturze finansowania poszczególnych kierunków wsparcia miał zakup sprzętu (40,6\%). Znaczącą część stanowiły także zakup leków $(34,4 \%)$ oraz zakup pszczół (21,1\%). Marginalne znaczenie miały pozostałe działania (żadne z nich nie przekroczyło udziału na poziomie $2 \%$ ). Szczegółowa struktura wypłaconych środków została przedstawiona na rysunku 4.

Bardzo istotnym elementem badań dopełniającym pełen obraz realizacji Programu Wsparcia Rynku Produktów Pszczelich przez WZP w Poznaniu były badania ankietowe, które miały na celu zapoznanie się z preferencjami pszczelarzy dotyczącymi wsparcia pszczelarstwa środkami pochodzącymi z UE oraz określenia ich zadowolenia i chęci skorzystania ze środków w przyszłości. 64,66\% zapytanych pszczelarzy korzystało ze wsparcia w ramach Programów Wsparcia Rynku Produktów Pszczelich. 88,37\% z korzystających ze wsparcia do tej pory oraz 70,21\% pszczelarzy, którzy nie korzystali ze wsparcia, chce z niego skorzystać w przyszłości. 92,86\% pszczelarzy korzystających 3 razy, 85,71\% korzystających 2 razy, 76,67\% korzystających 1 raz oraz 70,21\% nie korzystających ani razu chce skorzystać z finansowania w przyszłości. Wynika z tego fakt, że im więcej razy pszczelarze uczestniczyli w programie wsparcia, tym bardziej chca uczestniczyć po raz kolejny. Spośród wszystkich badanych $51,88 \%$ chce powiększać pasiekę, w tym 47,19\% korzystających oraz 57,45\% nie korzystających do tej pory. Spośród chcących korzystać ze wsparcia 57,80\% chce powiększyć pasiekę, z kolei 36,70\% nie zamierza zmieniać jej rozmiarów. Można zatem uznać, że większość pszczelarzy uzależnia powiększenie pasieki od otrzymanego w przyszłości wsparcia.

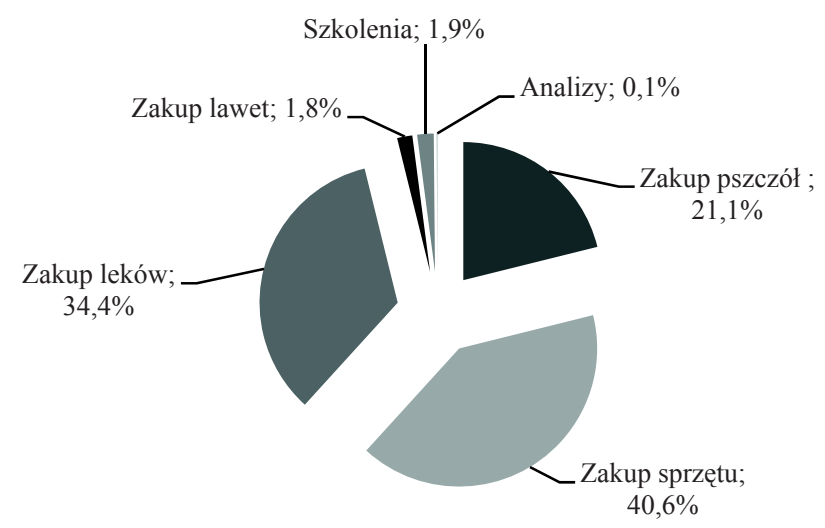

Rys. 4. Struktura wypłaconych środków finansowych WZP w Poznaniu w ramach Programów „Wsparcia Rynku Produktów Pszczelich" w latach 2012-2016

Fig. 4. Structure of funds paid to the Provincial Beekeepers Association in Poznań under the "Support of the Bee Products Market" programs in 2012-2016

Źródło: opracowanie własne na podstawie danych WZP w Poznaniu. 


\section{Podsumowanie}

Pszczelarstwo w województwie Wielkopolskim ma niezwykle istotne znaczenie gospodarcze. Świadczy o tym przede wszystkim areał upraw roślin entomofilnych, takich jak rzepak. Dlatego tak ważne jest, aby w jak największym stopniu zapewnić odpowiednie napszczelenie, dzięki czemu możliwe będzie zapylanie wszystkich roślin, które tego wymagają. Wśród zapylaczy największe znaczenie ma pszczoła miodna, która w dzisiejszych czasach dla właściwego rozwoju wymaga odpowiedniej opieki, którą zapewniają jej osoby zajmujące się pszczelarstwem. To właśnie zapylanie roślin jest główną przesłanką do użytkowania pszczół, a efekty z tego płynące można zaliczyć do kategorii dóbr publicznych, ponieważ przynoszą korzyści całemu społeczeństwu. W pełni uzasadnia to podejmowanie działań wspierających pasieki, zwłaszcza tych wdrażanych przez Unię Europejską. W Polsce działania te są realizowane przy pomocy Programów Wsparcia Rynku Produktów Pszczelich, które bezpośrednio do pasiek są implementowane przez poszczególne związki pszczelarzy.

Jak wykazała analiza, pszczelarze zrzeszeni w Wojewódzkim Związku Pszczelarzy w Poznaniu stanowią około $1 / 4$ wszystkich pszczelarzy $\mathrm{w}$ Wielkopolsce, jednak $\mathrm{w}$ ich pasiekach występuje większa koncentracji pni pszczelich (średnio o 5 uli w pasiece). Środki pochodzące z UE w znaczącym stopniu przyczyniają się do rozwoju wielkopolskiego pszczelarstwa. Jednak pomimo ich istotnego znaczenia, nadal nie są wykorzystywane w całości. Z drugiej strony powoduje to istnienie potencjału do dalszego rozwoju pasiek. Dominującymi kierunkami wsparcia są zakup sprzętu, zakup leków oraz zakup pszczół, zaś pozostałe kierunki mają marginalne znaczenie. Największa liczba beneficjentów korzystała jednak z zakupu leków, zakupu pszczół oraz szkoleń. Im więcej razy pszczelarze uczestniczyli w programie wsparcia, tym bardziej chcą uczestniczyć po raz kolejny. Większość pszczelarzy, którzy nie korzystali do tej pory ze wsparcia, a także tych chcących korzystać z programów w przyszłości, zamierza powiększyć pasiekę.

Rezultaty niniejszych badań wskazują na potrzebę dalszej i jeszcze bardziej dogłębnej eksploracji zagadnień związanych z ekonomiką pszczelarstwa oraz jego wsparcia przy pomocy środków pomocowych pochodzących z Unii Europejskiej. Należałoby także określić zasadność tego wsparcia, zwłaszcza w kontekście wynagradzania pszczelarzy za świadczone dobra publiczne, co planowane jest w dalszych badaniach związanych $\mathrm{z}$ omawianym zagadnieniem.

\section{Literatura}

Agencja Rynku Rolnego, (2006-2017). Sprawozdania z działalności Agencji Rynku Rolnego (w latach 20052016) (Reports on the activity of the Agricultural Market Agency (in the years 2005-2016)), Warszawa.

Bolisęga, E. (2004). Wsparcie produkcji i zbytu miodu (Support for the production and sale of honey). Biuletyn Informacyjny ARR, 12(162), 32-36.

Borowska, A. (2011). Stan i perspektywy rozwoju pszczelarstwa w Polsce ze szczególnym uwzględnieniem miodów regionalnych (The State and Perspective of the Development of Beekeeping in Poland with Particular Regard to Regionally Specific Honey). Zeszyty Naukowe SGGW Problemy Rolnictwa Światowego, 11(26), 4, 37-47.

Karliński, S. (2015). Podnoszenie rentowności w gospodarstwie pasiecznym (Raising Profitability in an Apiary). Gospodarka w Praktyce i Teorii; 3 (s. 39-64). Wydawnictwo Uniwersytetu Łódzkiego. 


\section{K.P. Pawłowski}

Madras-Majewska, B., Majewski, J. (2006). Opłacalność i perspektywy produkcji miodu w Polsce (The profitability of and perspectives for honey production in Poland). Zeszyty Naukowe SGGW Problemy Rolnictwa Światowego, 15, 58-68.

Majewski, J. (2012). Wsparcie pszczelarstwa po wejściu Polski do Unii Europejskiej (The beekeeping suport after Poland's accession to the European Union). Roczniki Naukowe Stowarzyszenia Ekonomistów Rolnictwa i Agrobiznesu, 14 (2), 113-117.

Majewski, J. (2015). Finansowe wsparcie polskiego pszczelarstwa środkami Unii Europejskiej (The financial support of Polish beekeeping by European Union's funds). Zeszyty Naukowe SGGW Ekonomika $i$ Organizacja Gospodarki Żywnościowej, 110, 67-79.

Majewski, J. (2017). Rola owadów zapylających w zapewnieniu bezpieczeństwa żywnościowego Polski (The role of pollinating insects in ensuring food security in Poland). Roczniki Naukowe Stowarzyszenia Ekonomistów Rolnictwa i Agrobiznesu, 19(3), 182-187.

Ostrowska, W. (1988). Gospodarka pasieczna (Apiary management). Państwowe Wydawnictwo Rolnicze i Leśne, Warszawa.

Pawłowski, K.P. (2017). Sytuacja ekonomiczna gospodarstw pasiecznych województwa wielkopolskiego (Economic situation of apiary farms in the Wielkopolskie voivodship). W: W. Czubak, A. Grzelak (red.) Gospodarka żywnościowa i obszary wiejskie w Polsce oraz na świecie wobec współczesnych wyzwań ekonomiczno-społecznych (s. 89-100). Wydawnictwo Kujawsko-Pomorskiej Szkoły Wyższej w Bydgoszczy.

Rozporządzenie Parlamentu Europejskiego i Rady (UE) nr 1308/2013 (Regulation (EU) No 1308/2013 of the European Parliament and of the Council).

Rozporządzenie Rady (WE) nr 1234/2007. (Council Regulation (EC) No 1234/2007).

Semkiw, P. (2017). Sektor pszczelarski w Polsce w 2017 roku (Beekeeping sector in Poland in 2017). Instytut Ogrodnictwa, Zakład Pszczelnictwa w Puławach.

Do cytowania / For citation:

Pawłowski K.P. (2018). Rola środków pochodzących z Unii Europejskiej w rozwoju pszczelarstwa na przykładzie Wojewódzkiego Związku Pszczelarzy w Poznaniu. Problemy Rolnictwa Światowego, 18(4), 382-394; DOI: 10.22630/PRS.2018.18.4.127

Pawłowski K.P. (2018). The role of funds from the European Union in the development of beekeeping on the example of the Provincial Union of Beekeepers in Poznań (in Polish). Problems of World Agriculture, 18(4), 382-394; DOI: 10.22630/PRS.2018.18.4.127 